Check for updates

Cite this: RSC Adv., 2018, 8, 26713

Received 14th May 2018

Accepted 27th June 2018

DOI: $10.1039 / \mathrm{c} 8 \mathrm{ra0} 4096 \mathrm{f}$

rsc.li/rsc-advances

\title{
Development of tungsten bronze nanorods for redox-enhanced photoacoustic imaging-guided photothermal therapy of tumors $\dagger$
}

Hongbo Gao, $\ddagger^{\mathrm{ab}}$ Xiangming Fang, $\dot{t}^{\mathrm{c}}$ Jing Xiang, ${ }^{\mathrm{d}}$ Xiaohang Liu, ${ }^{\mathrm{ab}}$ JianPing Zhang, ${ }^{\text {bef }}$ Bingni Zhou, ${ }^{\text {ab }}$ Bingxin Gu, ${ }^{\text {bef }}$ Hua Zhang, ${ }^{9}$ Wei Liu, ${ }^{\text {ab }}$ Yingying Zheng, ${ }^{\text {bef }}$ Yuyun Sun, ${ }^{\text {bef }}$ Yi Li, bef Wei Tang*ab and LiangPing Zhou (D) *ab

\begin{abstract}
Although various kinds of nanomaterials have been used as anticancer theranostics by exploiting the tumor microenvironment, relatively few nanomaterials can be efficiently activated by the tumor redox status for imaging and therapy. Oxygen-deficient tungsten-based oxides or bronzes are appearing as new classes of near-infrared (NIR)-responsive nanomaterials due to their unique properties such as tunable and broad NIR absorption. Herein, we synthesized $\mathrm{PEG}-\mathrm{Na}_{x} \mathrm{WO}_{3}$ nanorods (NRs) by a simple thermal decomposition method and investigated their redox-activated performance for enhanced photoacoustic (PA) imaging and photothermal therapy (PTT) of cancers. Both in vitro and in vivo studies revealed that such a novel class of tungsten bronzes with low toxicity could be used as efficient photothermal agents for PA imaging-guided PTT of cancers.
\end{abstract}

\section{Introduction}

The tumor microenvironment (e.g., hypoxia, redox state, acidic $\mathrm{pH}$, and so forth) has enabled tumor cells to evade or defend against the damage caused by traditional therapeutics such as radiotherapy, photodynamic therapy, chemotherapy, etc. ${ }^{1-3}$ Fast development of nano-therapy has provided promising perspectives, approaches, and strategies for anticancer therapy by exploiting the tumor microenvironment. ${ }^{4-7}$ Amongst all the physiological parameters, redox status plays an important role in the tumor to counteract tumor aggressive oxidative stresses by upregulating the redox species (e.g., glutathione, superoxide dismutase, catalase, and glutathione peroxidase). ${ }^{8,9}$ Among

${ }^{a}$ Department of Radiology, Fudan University Shanghai Cancer Center, Shanghai 200032,China.E-mail: zhoulp2006@163.com; tangwei105@163.com

${ }^{b}$ Department of Oncology, Shanghai Medical College, Fudan University, Shanghai 200032, China

'Department of Radiology, Wuxi People's Hospital, Nanjing Medical University, Wuxi, 214023, China

${ }^{d}$ Department of Ophthalmology, Affiliated Hospital of Nantong University, Natong 226001, Jiangsu Province, China

${ }^{e}$ Department of Nuclear Medicine, Fudan University Shanghai Cancer Center, Shanghai, 200032, China

${ }^{f}$ Shanghai Engineering Research Center of Molecular Imaging Probes, Shanghai, 200032, China

${ }^{g}$ Department of Radiology, Huashan Hospital of Fudan University, Shanghai 200040, China

$\dagger$ Electronic supplementary information (ESI) available. See DOI: 10.1039/c8ra04096f

\$ Hongbo Gao and Xiangming Fang contributed equally to this work. them, glutathione (GSH) is widely used as an indicator to assist cancer imaging or therapy since the levels of GSH in cancer tissues range from $0.5-10 \times 10^{-3} \mathrm{M},{ }^{10,11}$ which is four-fold higher than that of normal tissues.

Development of novel strategies to detect and utilize the redox status for imaging or enhanced nano-therapy in vivo is highly desirable, as these could improve therapeutic efficacy and simultaneously reduce the damage of anticancer agents to normal tissues. ${ }^{\mathbf{1 2 - 1 5}}$ By employing redox-activated molecules or nanomaterials, various approaches for monitoring the redox status have been reported, ${ }^{16,17}$ while relatively few cancer nanotherapies by exploiting tumor redox status have been reported so far. It is well known that photothermal therapy (PTT) can transform near-infrared (NIR) energy to heat for killing the tumor cells via hyperthermia or thermal ablation. ${ }^{\mathbf{1 8 - 2 2}}$ Meanwhile, PTT can also be combined with photoacoustic (PA) imaging for imaging-guided cancer treatment since both use NIR-responsive nanomaterials. ${ }^{23-25}$ The design and synthesis of redox-responsive nanomaterials which can be reduced in the tumor redox microenvironment to increase NIR absorption for enhanced PA imaging-guided PTT are of great significance to eliminate the side effects of traditional PTT.

The oxygen-deficient tungsten oxides $\left(\mathrm{WO}_{x}\right)$ and tungsten bronzes $\left(\mathrm{M}_{x} \mathrm{WO}_{3}\right)$ are promising photothermal agents because of their strong NIR photothermal conversion. ${ }^{26-38}$ Recently, Shi and co-workers reported that tunable oxygen vacancy concentrations could be regulated to enhance nanomaterials' magnetic resonance imaging performance due to the high affinity between the oxygen vacancies and water molecules. ${ }^{38}$ Such critical features of tunable oxygen vacancies of tungsten 
bronzes under oxidized/redox status could be further applied to the GSH-enhanced photothermal conversion. Herein, oxygendeficient PEGlyated $\mathrm{Na}_{x} \mathrm{WO}_{3}$ nanorods (NRs) were synthesized to explore their properties and applications as theranostics for enhanced PTT in the tumor redox microenvironment. We found that the photothermal properties of $\mathrm{Na}_{x} \mathrm{WO}_{3}$ NRs were strengthened after GSH incubation, which was demonstrated by various in vitro experiments including PA imaging of NRcontaining aqueous and GSH-responsive PTT therapy on 4T1 tumor cells. Furthermore, PA imaging-guided PTT of tumors was successfully achieved on 4T1 tumor-bearing mice after intravenous injection of $\mathrm{Na}_{x} \mathrm{WO}_{3}$ NRs.

\section{Experimental}

\subsection{Materials}

Sodium tungstate dihydrate $\left(\mathrm{Na}_{2} \mathrm{WO}_{4} \cdot 2 \mathrm{H}_{2} \mathrm{O}\right)$ and ammonia solution $\left(\mathrm{NH}_{3} \cdot \mathrm{H}_{2} \mathrm{O}\right)$ were purchased from Sinopharm Chemical Reagent Co., Ltd. 1-Octadecene (90\%), oleic acid (OA), and cyclohexane $\left(\mathrm{C}_{6} \mathrm{H}_{12}\right)$ were obtained from Sigma-Aldrich. $\mathrm{SH}$ $\mathrm{PEG}_{5 \mathrm{k}}$ was acquired from Jenkem Co., Ltd. All reagents were of analytical grade and used without any purification.

\subsection{Synthesis of PEG-Na $\mathrm{WO}_{3}$ nanorods}

Typically, $2 \mathrm{mmol} \mathrm{Na}_{2} \mathrm{WO}_{4} \cdot 2 \mathrm{H}_{2} \mathrm{O}$ was dissolved in $5 \mathrm{~mL}$ ammonia solution and placed into a flask, and $10 \mathrm{~mL}$ oleic acid and $30 \mathrm{~mL}$ 1-octadecene were added to the flask. The mixture was then stirred at room temperature for $3 \mathrm{~h}$. After evaporation of ammonia at $80{ }^{\circ} \mathrm{C}$ under an argon atmosphere for $2 \mathrm{~h}$, followed by $120^{\circ} \mathrm{C}$ under an argon atmosphere for $2 \mathrm{~h}$, the solution was heated to $280{ }^{\circ} \mathrm{C}$ and maintained for $2 \mathrm{~h}$, then cooled down to room temperature. The product was centrifuged and dispersed in $20 \mathrm{~mL}$ cyclohexane. After washing with $10 \mathrm{~mL}$ ethanol, the mixed solution was centrifuged and the $\mathrm{Na}_{x} \mathrm{WO}_{3}$ nanorods (NRs) were finally dispersed in $15 \mathrm{~mL}$ DMSO. The PEG-Na $\mathrm{WO}_{3}$ NRs were prepared by strong thiol-metal interactions. Briefly, the as-synthesized $\mathrm{Na}_{x} \mathrm{WO}_{3}$ NRs were re-dispersed in $15 \mathrm{~mL}$ deionized water, followed by addition of $5 \mathrm{~mL}$ deionized water containing $500 \mathrm{mg} \mathrm{SH}-\mathrm{PEG}_{5 \mathrm{k}}$, and stirred for $48 \mathrm{~h}$ at room temperature. Excess free PEG was removed by centrifugation (20 $000 \mathrm{rpm}, 15 \mathrm{~min}$ ). The $\mathrm{PEG}-\mathrm{Na}_{x} \mathrm{WO}_{3} \mathrm{NRs}$ were dispersed in water or PBS for future experiments.

\subsection{Photothermal evaluation of PEG-Na $\mathrm{WO}_{3} \mathrm{NRs}$}

An aqueous solution containing PEG- $\mathrm{Na}_{x} \mathrm{WO}_{3} \mathrm{NRs}$ before and after incubation with different concentrations of $5 \mathrm{mM}$ and $10 \mathrm{mM}$ GSH was poured into a quartz cuvette. The cuvette was illuminated by a $980 \mathrm{~nm}$ laser with power density $1.5 \mathrm{~W} \mathrm{~cm}^{-2}$ for $5 \mathrm{~min}$. The increase curves of temperature were monitored by FLIR ${ }^{\mathrm{TM}}$ A320 camera.

\subsection{Cytotoxicity assessment}

Murine breast carcinoma tumor 4T1 cells and murine macrophage cells (RAW 264.3) cells were cultured in Roswell Park Memorial Institute medium 1640 supplemented with $10 \%$ fetal bovine serum and $1 \%$ penicillin/streptomycin at $37{ }^{\circ} \mathrm{C}$ under
$5 \% \mathrm{CO}_{2}$. Human embryonic kidney 293 (HEK293) cells were cultured under $5 \% \mathrm{CO}_{2}$ at $37{ }^{\circ} \mathrm{C}$ in Dulbecco's Modified Eagle Medium supplemented with $1 \%$ penicillin/streptomycin and $10 \%$ fetal bovine serum. The cells were seeded into a 96-well cell culture plate at $10^{5}$ per well and after $24 \mathrm{~h}$ incubation, PEG$\mathrm{Na}_{x} \mathrm{WO}_{3} \mathrm{NRs}$ with different concentrations $(0.025,0.05,0.1,0.2$ and $0.4 \mathrm{mg} \mathrm{mL}^{-1}$ ) were put into the wells and then incubated for another $24 \mathrm{~h}$ or $48 \mathrm{~h}$ at $37^{\circ} \mathrm{C}$ under $5 \% \mathrm{CO}_{2}$. Cell viability was determined by an MTT assay.

For photothermal ablation of $4 \mathrm{~T} 1$ cells in vitro, the $4 \mathrm{~T} 1$ cells were seeded into the 96-well plate at a density of $10^{5}$ per well and then incubated at $37{ }^{\circ} \mathrm{C}$ under $5 \% \mathrm{CO}_{2}$ for $24 \mathrm{~h}$. The PEG$\mathrm{Na}_{x} \mathrm{WO}_{3} \mathrm{NRs}$ reduced by GSH ( 5 and $10 \mathrm{mM}$ ) were dispersed in cell culture media with different concentrations (0.08, and $\left.0.16 \mathrm{mg} \mathrm{mL}^{-1}\right)$. After $4 \mathrm{~h}$ incubation, the cells were exposed to the $980 \mathrm{~nm}$ laser $\left(1.5 \mathrm{~W} \mathrm{~cm}^{-2}\right)$ for $5 \mathrm{~min}$ and then incubated for $20 \mathrm{~h}$. The cell viability was calculated by the MTT assay.

\subsection{Trypan blue stain}

PBS containing PEG-Na $\mathrm{WO}_{3}$ NRs $\left(0.16 \mathrm{mg} \mathrm{mL}{ }^{-1}\right)$ was added to a cell culture plate containing 4T1 cells and incubated for $24 \mathrm{~h}$. Then cells were irradiated with the $980 \mathrm{~nm}$ laser $\left(1.5 \mathrm{~W} \mathrm{~cm}^{-2}\right)$ for $5 \mathrm{~min}$, followed by staining with $0.4 \%$ trypan blue solution for $15 \mathrm{~min}$. Then, the cells were washed with PBS three times, and cell morphology of the cells was monitored by an inverted optical microscope (Olympus, IX71, Japan). Cells stained with blue were dead cells.

\subsection{Tumor models}

All animal procedures were under the guidelines of the Institutional Animal Care and Use Committee of Fudan University. All Balb/c or Kunming mice with an average weight of $20 \mathrm{~g}$ were purchased from the Laboratory Animal Centre, Shanghai Medical College of Fudan University, China. The 4T1 tumorbearing models were generated by subcutaneously injecting $4 \mathrm{~T} 1$ cells $\left(10^{6}\right.$ in $100 \mu \mathrm{L}$ PBS $)$ on the right front leg region of the $\mathrm{Balb} / \mathrm{c}$ mice. The mice were used when their tumor volumes reached about $80 \mathrm{~mm}^{3}$.

\subsection{PA imaging in vitro and in vivo}

To investigate the redox-activated PA imaging, PEG-Na $\mathrm{WO}_{3}$ NRs were incubated with different concentrations of GSH $(0,10$, and $15 \mathrm{mM}$ ) for $12 \mathrm{~h}$ and then were used for in vitro PA imaging.

Since the levels of GSH in cancer tissues range from 0.5-10 $\times$ $10^{-3} \mathrm{M},{ }^{10,11}$ for in vivo PA imaging, the $4 \mathrm{~T} 1$ tumor-bearing mice were put on a Vevo LAZR instrument, and the tumor was covered with ultrasonic coupling gel. PA imaging was performed before intravenous injection of PEG-Na $\mathrm{WO}_{3}$ NRs (150 $\left.\mu \mathrm{L}, 3 \mathrm{mg} \mathrm{mL}{ }^{-1}\right)$ and at different time $(1,2,24 \mathrm{~h})$ points postinjection (p.i.).

\subsection{In vivo photothermal imaging and therapy}

For in vivo photothermal therapy, 4T1 tumor-bearing mice were randomly divided into four treatment groups: (1) PBS alone; (2) PEG-Na $\mathrm{WO}_{3}$ NRs alone; (3) NIR alone; (4) PEG-Na $\mathrm{WO}_{3} \mathrm{NRs}+$ 
NIR. A dosage of PEG-Na $\mathrm{WO}_{3}$ NRs $\left(150 \mu \mathrm{L}, 3 \mathrm{mg} \mathrm{mL}{ }^{-1}\right.$ in saline) was intravenously injected into the mice in groups 2 and 4. The mice in group 4 were then exposed to a $980 \mathrm{~nm}$ laser with an output power density of $1.5 \mathrm{~W} \mathrm{~cm}^{-2}$ (duration time: $5 \mathrm{~min}$ ) at $2 \mathrm{~h}$ p.i. The same power density and duration time of the laser were applied on the mice in group 3 as a control. Photothermal imaging was recorded using the FLIR ${ }^{\mathrm{TM}}$ A320 camera. The tumor volume of mice in the different groups were recorded every two days for two weeks. Relative tumor volume $\left(V / V_{0}\right.$, where $V_{0}$ represents the initial tumor volume), body weight, and tumor appearance were monitored. Hematoxylin-eosin (H\&E) staining was performed at two days after the corresponding treatment.

\subsection{Histological assessment}

The standard H\&E staining was conducted to monitor in vivo biocompatibility of PEG- $\mathrm{Na}_{x} \mathrm{WO}_{3}$ nanorods. Tissues (heart, liver, spleen, lung and kidney) of the Kunming mice were dissected for H\&E staining after intravenous injection of NRs ( $300 \mu \mathrm{L}, 3 \mathrm{mg} \mathrm{mL}^{-1}$ in saline) at two weeks and one month p.i. The histological sections were observed under an optical microscope.

\section{Results and discussions}

Tungsten bronzes $\left(\mathrm{Na}_{x} \mathrm{WO}_{3}\right)$ were achieved using a modified thermal decomposition approach, ${ }^{\mathbf{4 0}}$ along with poly(ethylene glycol)-thiol modification through the strong coordination interactions between metal cations and thiol groups to further improve their biocompatibility. ${ }^{41-43}$ Transmission electron microscopy (TEM) images of the PEG- $\mathrm{Na}_{x} \mathrm{WO}_{3}$ NRs revealed an average size of around $30 \mathrm{~nm}$ in width and $130 \mathrm{~nm}$ in length (Fig. 1a and S1 $\dagger$ ). The HRTEM image indicated the NRs' crystalline nature (Fig. 1b), and the energy-dispersive X-ray (EDX) spectrum (Fig. 1c) demonstrated the presence of all expected essential chemical elements ( $\mathrm{Na}, \mathrm{W}$, and $\mathrm{O})$. As shown in Fig. 1d, the X-ray diffraction pattern showed that the as-made NRs contained a $\mathrm{Na}_{x} \mathrm{WO}_{3}$ phase structure. All the above results demonstrated that the tungsten bronzes were successfully synthesized. The obtained PEG-Na $\mathrm{N}_{x} \mathrm{WO}_{3}$ NRs exhibited excellent stability in aqueous solution (insert in Fig. 1a and $\mathrm{S} 2 \dagger$ ) and their hydrated size was $\sim 219.9 \mathrm{~nm}$ with a low PDI of 0.140 (Fig. S3†), as measured by dynamic light scattering (DLS).

The UV-vis-NIR spectra of the PEG-Na $\mathrm{WO}_{3}$ NRs showed a broad NIR absorption band from $700 \mathrm{~nm}$ to $1200 \mathrm{~nm}$ (Fig. 2a), which was very similar to the behavior of previously reported tungsten oxides and tungsten bronzes. ${ }^{33,39}$ Importantly, after incubation with GSH, the absorption of NRs enhanced gradually as the GSH concentration increased. The morphology of PEG-Na $\mathrm{NO}_{3}$ NRs remained unchanged after GSH reduction (Fig. S4†). GSH reduction was supposed to occur on the surface of nanorods, which would not alter the nanorod's shape. The spectral difference indicated that the oxygen vacancy concentration on the surface of the NRs was increased after reduction by GSH, which is caused by the partial valence decrease of $\mathrm{W}^{6+}$ to $\mathrm{W}^{5+}$. PA images of PEG-Na $\mathrm{N}_{x} \mathrm{WO}_{3} \mathrm{NRs}$ with and without GSH incubation further demonstrated the NRs' redox-activated performance, where the samples with higher levels of reduction exhibited higher PA signal intensities (Fig. 2b). Then, the PEG-Na $\mathrm{WO}_{3}$ NRs were exposed to a $980 \mathrm{~nm}$ laser $\left(1.5 \mathrm{~W} \mathrm{~cm}^{-2}\right)$ to evaluate their photothermal conversion. As shown in Fig. 2c, the temperature of the PEG- $\mathrm{Na}_{x} \mathrm{WO}_{3} \mathrm{NR}$ dispersed aqueous solution increased rapidly over $5 \mathrm{~min}$, while pure water showed a limited temperature change under irradiation. Furthermore, we found that the solutions with higher GSH concentrations exhibited higher temperature change, which was consistent with the above results, demonstrating that the PEG-Na $\mathrm{WO}_{3}$ NRs after redox-activation were more efficient at transforming light-energy to heat. a)

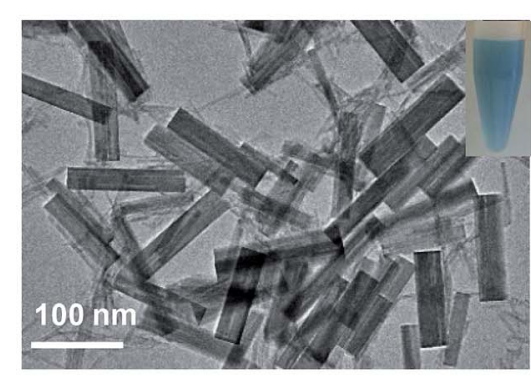

c)

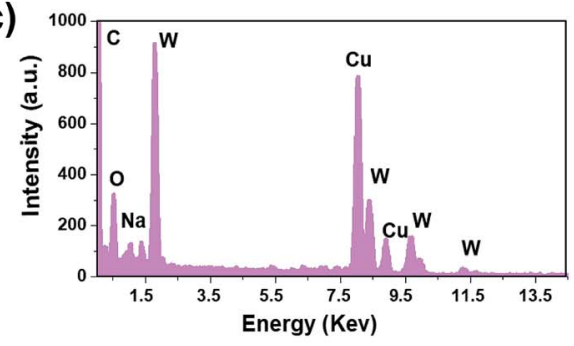

b)

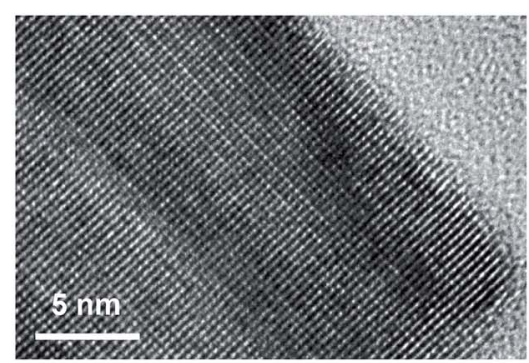

d)

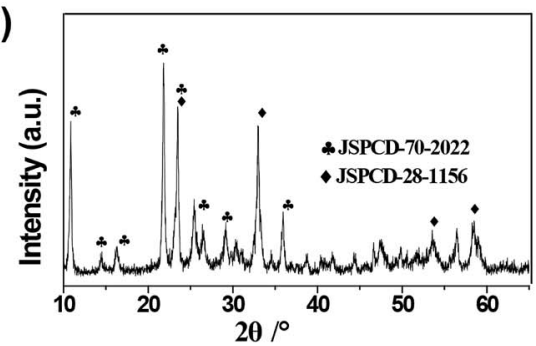

Fig. 1 (a) TEM image of PEG-Na $\mathrm{WO}_{3}$ NRs dispersed in water. (b) High-resolution TEM image of one nanorod. (c) EDX spectrum and (d) XRD of $\mathrm{Na}_{x} \mathrm{WO}_{3} \mathrm{NRs}$. 
a)

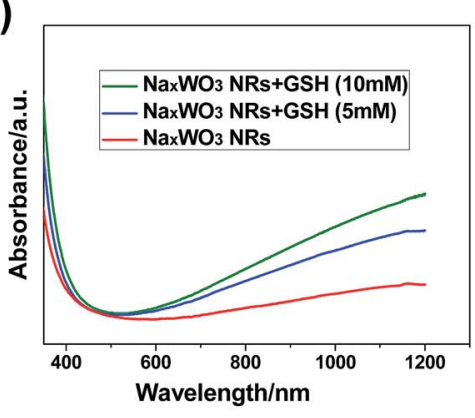

b)

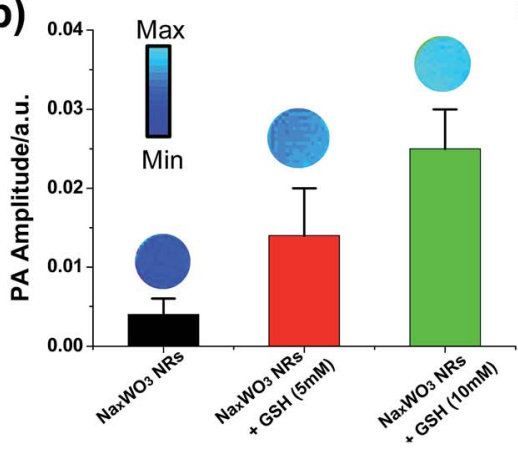

c)

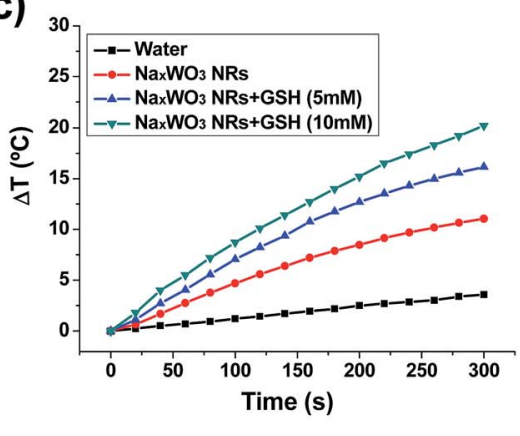

Fig. 2 (a) UV-vis-NIR absorption spectra of an aqueous dispersion containing PEG- $\mathrm{Na}_{x} \mathrm{WO}_{3} \mathrm{NRs}$ before and after reduction by GSH with different concentrations. (b) PA imaging and PA signal of PEG- $\mathrm{Na}_{x} \mathrm{WO}_{3} \mathrm{NRs}$ before and after incubation with different concentrations of GSH (control, 5, and $10 \mathrm{mM}$ ). (c) The temperature increase curves of pure water and aqueous dispersions of $\mathrm{PEG}-\mathrm{Na}_{x} \mathrm{WO}_{3} \mathrm{NRs}$ without or with GSH incubation when exposed to $980 \mathrm{~nm}$ laser irradiation for $5 \mathrm{~min}$.

Before conducting imaging and therapy experiments in vivo, a standard MTT assay was conducted to evaluate the cytotoxicity of PEG-Na $\mathrm{WO}_{3}$ NRs at various concentrations $(0.025,0.05,0.1$, 0.2 , and $0.4 \mathrm{mg} \mathrm{mL}^{-1}$ ), which exhibited negligible toxicity to $4 \mathrm{~T} 1$ cells and normal cell lines (i.e., RAW264.3 and HEK293 cells) at both $24 \mathrm{~h}$ and $48 \mathrm{~h}$ incubation (Fig. $3 \mathrm{a}$ and $55 \dagger$ ), demonstrating that PEGlyation of nanomaterials can significantly enhance the biocompatibility. Subsequently, the PEG-Na $\mathrm{WO}_{3}$ NRs reduced by different concentrations of GSH ( 5 and $10 \mathrm{mM}$ ) were incubated with $4 \mathrm{~T} 1$ cells, followed by exposure to the $980 \mathrm{~nm}$ laser for $5 \mathrm{~min}$ at the power of $1.5 \mathrm{~W} \mathrm{~cm}^{-2}$. As shown in Fig. 3b, more cells were killed upon NIR laser irradiation with stronger reducing levels or higher concentrations of PEG-Na $\mathrm{WO}_{3}$ NRs. Furthermore, trypan blue staining was performed to confirm the MTT results, which could differentiate dead cells from live cells (Fig. 3c). Most of the tumor cells treated with nanorods and NIR exposure were killed, while only negligible dead cells were observed for the groups without any treatment, or treatment with nanorods or NIR laser irradiation only.

Encouraged by these in vitro findings, we then performed the in vivo PA along with ultrasound images on $4 \mathrm{~T} 1$ tumor-bearing mice prior to, and at different time points after, intravenous injection of PEG-Na $\mathrm{WO}_{3}$ NRs. As shown in Fig. $4 \mathrm{a}$ and $\mathrm{S} 6, \uparrow$ the ultrasound images could visualize the tumor anatomy (e.g., skin and inclusion edge), while the PA images were utilized to reveal the accumulation of NIR-responsive PEG-Na $\mathrm{WO}_{3}$ NRs. The PA imaging signal was clearly detected in the tumors after injection, which reached the highest at $2 \mathrm{~h}$ p.i., demonstrating that PEG-Na $\mathrm{WO}_{3}$ NRs could act as PA imaging agents after accumulation in the tumor by the well-known enhanced a)

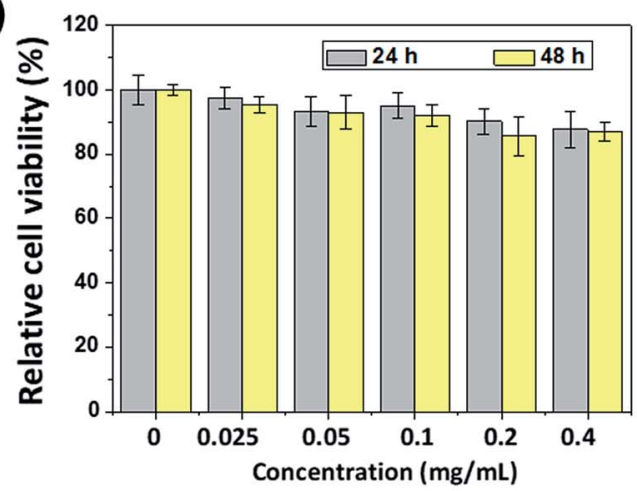

c)

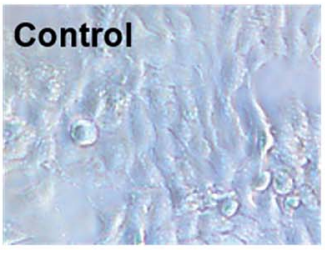

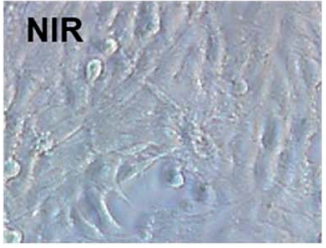

b)
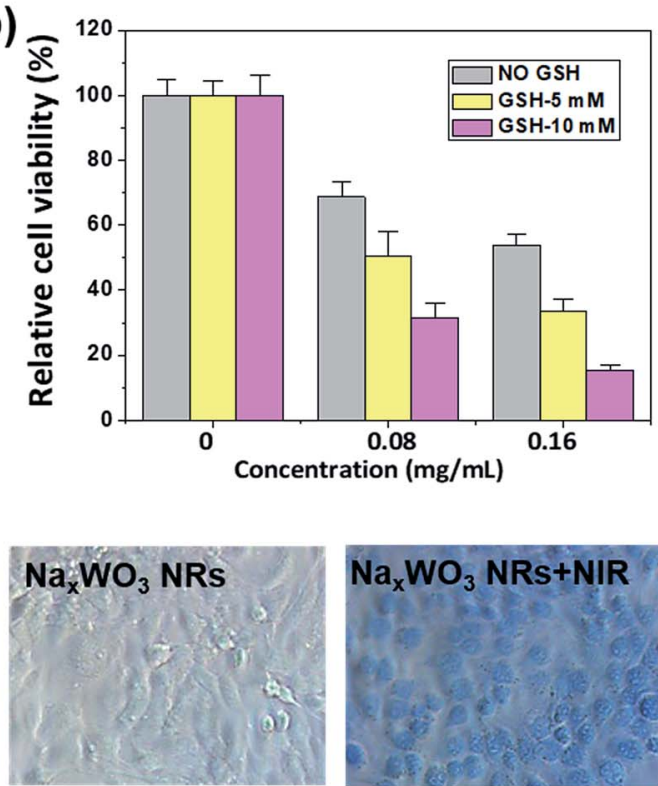

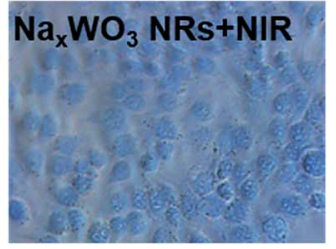

Fig. 3 (a) Relative viabilities of $4 \mathrm{~T} 1$ cells after incubation with different concentrations of PEG-Na $\mathrm{WO}_{3} \mathrm{NRs}$. (b) Relative viabilities of $4 \mathrm{~T} 1$ cells after photothermal therapy at varied concentrations of PEG- $\mathrm{Na}_{x} \mathrm{WO}_{3} \mathrm{NRs}$ reduced by different GSH concentrations under 980 nm NIR laser irradiation for $5 \mathrm{~min}$. (c) Optical microscopy images of 4T1 cells stained with trypan blue after various treatments indicated. 

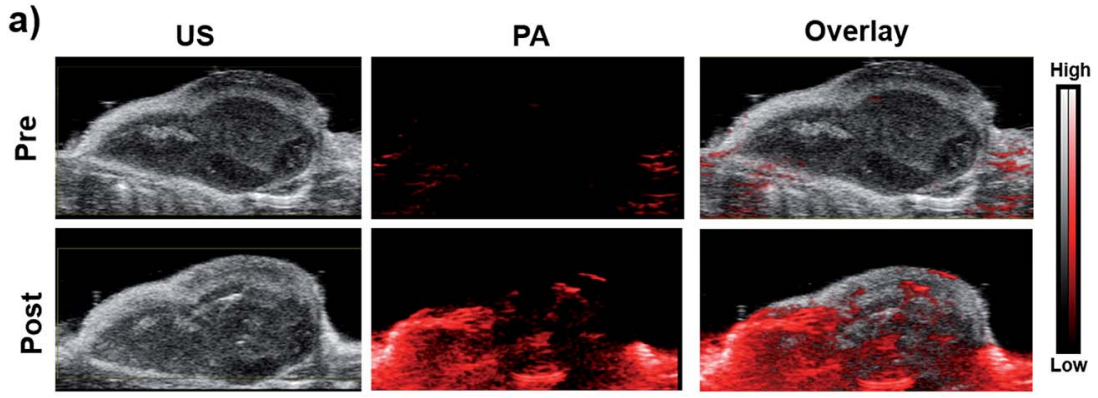

b) 0
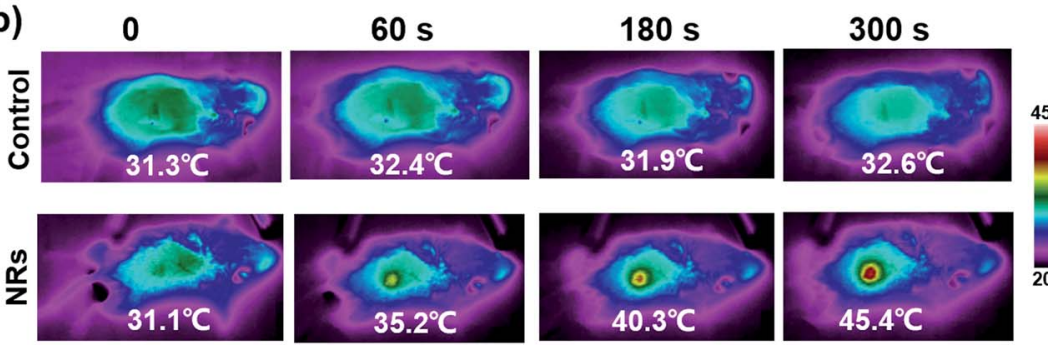

Fig. 4 (a) In vivo PA images of $4 \mathrm{~T} 1$ tumor-bearing mice before and after intravenous injection with $\mathrm{PEG}-\mathrm{Na}_{x} \mathrm{WO} \mathrm{NRs}_{3} \mathrm{NR}_{2} \mathrm{~h}$ p.i. (b) In vivo photothermal images of 4T1 tumor-bearing mice before and after intravenous injection with PEG-Na $\mathrm{WO}_{3} \mathrm{NRs}$ at $2 \mathrm{~h}$ p.i. under continuous $980 \mathrm{~nm}$ laser irradiation.

permeability and retention (EPR) effect. Since the GSH content in the tumor tissues is relatively high, ${ }^{10,11}$ partial PA imaging signals may be attributed to the redox-activated characteristics of PEG-Na $\mathrm{WO}_{3}$ NRs. For photothermal imaging, the tumor temperatures without and with $\mathrm{PEG}-\mathrm{Na}_{x} \mathrm{WO}_{3}$ NRs treatment were increased by $1.3{ }^{\circ} \mathrm{C}$ and $14.3^{\circ} \mathrm{C}$, respectively, within 5 min of $980 \mathrm{~nm}$ laser irradiation (Fig. 4b). The highest temperature of a $\mathrm{Na}_{x} \mathrm{WO}_{3}$ NRs treated tumor reached about $45.4{ }^{\circ} \mathrm{C}$, which could thereby kill cancer cells via hyperthermia $\left(40-45{ }^{\circ} \mathrm{C}\right)$. These results confirm that the PEG-Na $\mathrm{WO}_{3}$ NRs can serve as

\section{a)}

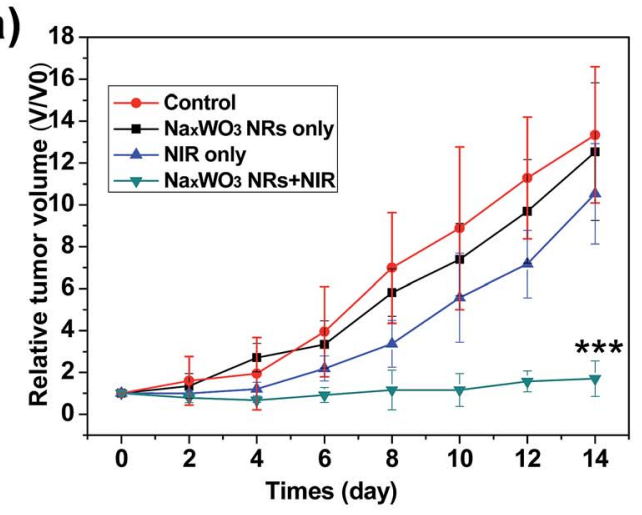

c)
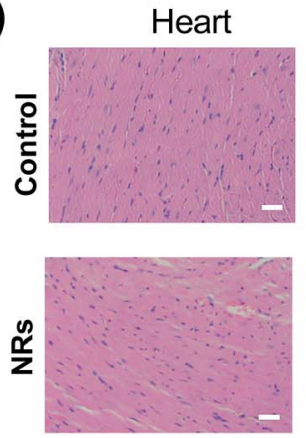

Lung
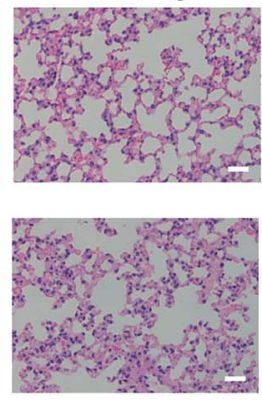

b)
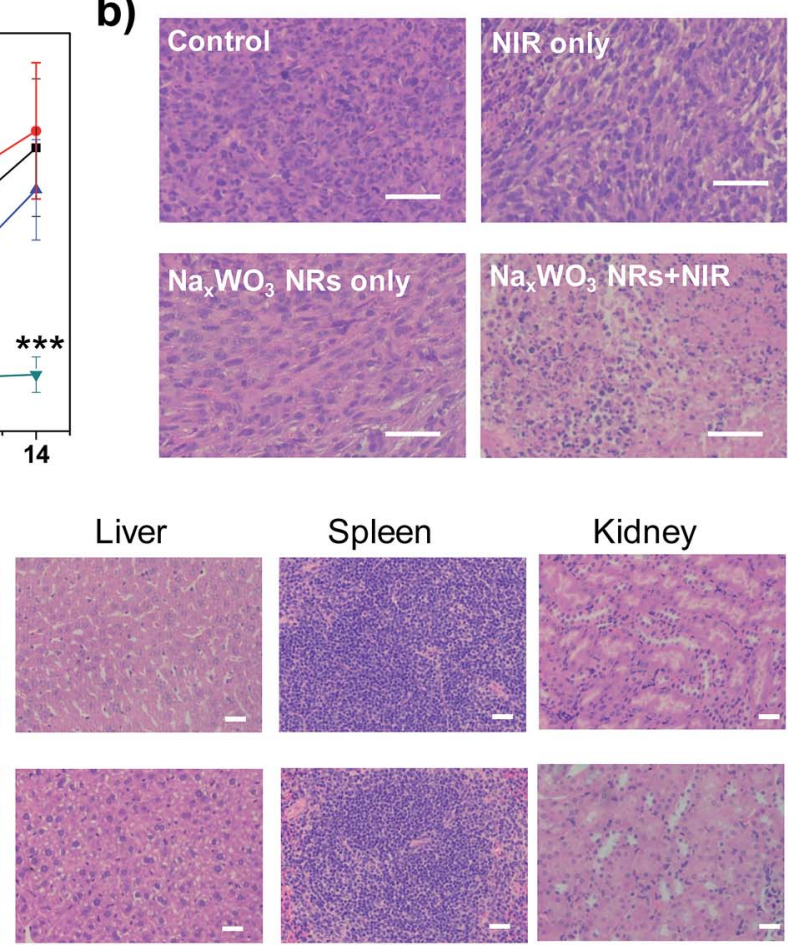

Fig. 5 (a) Relative tumor growth profiles of 4 T1 tumor-bearing mice after various treatments indicated (for each group, $n=4$, mean \pm s.d., *** $P<$ 0.001 , versus control). (b) The H\&E staining of tumor tissues obtained from mice in different groups. Scale bar: $50 \mu \mathrm{m}$. (c) The H\&E staining of major organs from mice after intravenous injection of $\mathrm{PEG}-\mathrm{Na}_{x} \mathrm{WO}_{3} \mathrm{NRs}$ at two weeks. 
a sensitive PA imaging contrast agent for imaging-guided PTT of cancers.

As shown in Fig. 5a, the tumor growth is substantially inhibited by intravenous injection of PEG- $\mathrm{Na}_{x} \mathrm{WO}_{3} \mathrm{NRs}$ under $980 \mathrm{~nm}$ laser irradiation, while the control, NRs, and NIR treated groups showed rapid tumor growth. Meanwhile, hematoxylin and eosin (H\&E) staining of tumor tissues' histological changes further confirmed the above tumor growth results, where therapy groups showed the most tumor damage. In two weeks, neither significant weight loss nor any abnormal behavior were observed in any of the groups (Fig. S7†), indicating no noticeable side effects of the NRs. The H\&E stained images of different organs (heart, liver, spleen, lung, and kidney) on normal mice revealed negligible organ damage or inflammatory lesions both in two weeks and one month (Fig. 5b and $\mathrm{S} 8 \dagger$ ), indicating the low toxicity of PEG-Na $\mathrm{WO}_{3}$ NRs.

\section{Conclusion}

In summary, the novel oxygen-deficient PEG-Na $\mathrm{WO}_{3}$ NRs were successfully synthesized and used for PA imaging-guided PTT. Upon application of $980 \mathrm{~nm}$ NIR light, the photothermal effect of PEG- $\mathrm{Na}_{x} \mathrm{WO}_{3}$ NRs led to a rapid increase of local temperature, which could be further enhanced under the tumor redox microenvironment, as demonstrated both in aqueous solutions and $4 \mathrm{~T} 1$ cells in vitro. Moreover, PA imaging-guided photothermal therapy was also successfully achieved on 4T1 tumorbearing mice in vivo. Our results not only provide the tunable oxygen vacancy properties of tungsten bronzes for PA imagingguided cancer therapies but also encourage further exploration of the tumor redox microenvironment for biomedical applications.

\section{Conflicts of interest}

The authors declare no competing financial interest.

\section{Acknowledgements}

This work has been financially supported by the National Natural Science Foundation of China (81271629) and the Shanghai Health and Family Planning Commission Youth Fund Project (20174Y0242). All animal procedures were performed in accordance with the Guidelines for Care and Use of Laboratory Animals of Fudan University and experiments were approved by the Animal Ethics Committee of Fudan University.

\section{References}

1 M. S. Yavuz, Y. Cheng, J. Chen, C. M. Cobley, Q. Zhang, M. Rycenga, J. Xie, C. Kim, K. H. Song, A. G. Schwartz, L. V. Wang and Y. Xia, Gold nanocages covered by smart polymers for controlled release with near-infrared light, Nat. Mater., 2009, 8, 935-939.

2 P. Mi, D. Kokuryo, H. Cabral, H. Wu, Y. Terada, T. Saga, I. Aoki, N. Nishiyama and K. Kataoka, A pH-activatable nanoparticle with signal-amplification capabilities for non- invasive imaging of tumour malignancy, Nat. Nanotechnol., 2016, 11, 724-730.

3 Y. Lu, A. A. Aimetti, R. Langer and Z. Gu, Bioresponsive materials, Nat. Rev. Mater., 2016, 2, 16075.

4 Y. Dai, C. Xu, X. Sun and X. Chen, Nanoparticle design strategies for enhanced anticancer therapy by exploiting the tumour microenvironment, Chem. Soc. Rev., 2017, 46, 3830-3852.

5 M. Overchuk and G. Zheng, Overcoming obstacles in the tumor microenvironment: Recent advancements in nanoparticle delivery for cancer theranostics, Biomaterials, 2018, 156, 217-237.

6 L. Wang, M. Huo, Y. Chen and J. Shi, Tumor Microenvironment-Enabled Nanotherapy, Adv. Healthcare Mater., 2017, 7, 1701156.

7 D. Huo, S. Liu, C. Zhang, J. He, Z. Zhou, H. Zhang and Y. Hu, Hypoxia-Targeting, Tumor Microenvironment Responsive Nanocluster Bomb for Radical-Enhanced Radiotherapy, ACS Nano, 2017, 11, 10159-10174.

8 E. H. Sarsour, M. G. Kumar, L. Chaudhuri, A. L. Kalen and P. C. Goswami, Redox control of the cell cycle in health and disease, Antioxidants Redox Signal., 2009, 11, 2985-3011.

9 A. Rubartelli and M. T. Lotze, Inside, outside, upside down: damage-associated molecular-pattern molecules (DAMPs) and redox, Trends Immunol., 2007, 28, 429-436.

10 H. J. Kim, A. Kim, K. Miyata and K. Kataoka, Recent progress in development of siRNA delivery vehicles for cancer therapy, Adv. Drug Deliv. Rev., 2016, 104, 61-77.

11 M. H. Lee, Z. Yang, C. W. Lim, Y. H. Lee, S. Dongbang, C. Kang and J. S. Kim, Disulfide-cleavage-triggered chemosensors and their biological applications, Chem. Rev., 2013, 113, 5071-5109.

12 S. Y. Lim, K. H. Hong, D. I. Kim, H. Kwon and H. J. Kim, Tunable heptamethine-azo dye conjugate as an NIR fluorescent probe for the selective detection of mitochondrial glutathione over cysteine and homocysteine, J. Am. Chem. Soc., 2014, 136, 7018-7025.

13 G. S. Loving, S. Mukherjee and P. Caravan, Redox-Activated Manganese-Based MR Contrast Agent, J. Am. Chem. Soc., 2013, 135, 4620-4623.

14 L. Yu, Y. Chen, M. Wu, X. Cai, H. Yao, L. Zhang, H. Chen and J. Shi, "Manganese Extraction" Strategy Enables TumorSensitive Biodegradability and Theranostics of Nanoparticles, J. Am. Chem. Soc., 2016, 138, 9881-9894.

15 D. Ni, W. Bu, E. B. Ehlerding, W. Cai and J. Shi, Engineering of inorganic nanoparticles as magnetic resonance imaging contrast agents, Chem. Soc. Rev., 2017, 46, 7438-7468.

16 D. Ni, D. Jiang, H. F. Valdovinos, E. B. Ehlerding, B. Yu, T. E. Barnhart, P. Huang and W. Cai, Bioresponsive Polyoxometalate Cluster for Redox-Activated Photoacoustic Imaging-Guided Photothermal Cancer Therapy, Nano Lett., 2017, 17, 3282-3289.

17 Y. Chen, P. Xu, Z. Shu, M. Wu, L. Wang, S. Zhang, Y. Zheng, H. Chen, J. Wang, Y. Li and J. Shi, Multifunctional Graphene Oxide-based Triple Stimuli-Responsive Nanotheranostics, Adv. Funct. Mater., 2014, 24, 4386-4396. 
18 X. Huang, W. Zhang, G. Guan, G. Song, R. Zou and J. Hu, Design and Functionalization of the NIR-Responsive Photothermal Semiconductor Nanomaterials for Cancer Theranostics, Acc. Chem. Res., 2017, 50, 2529-2538.

19 C. Zhang, W. Bu, D. Ni, C. Zuo, C. Cheng, Q. Li, L. Zhang, Z. Wang and J. Shi, A Polyoxometalate Cluster Paradigm with Self-Adaptive Electronic Structure for Acidity/ Reducibility-Specific Photothermal Conversion, J. Am. Chem. Soc., 2016, 138, 8156-8164.

20 J. Yu, Y. Ju, L. Zhao, X. Chu, W. Yang, Y. Tian, F. Sheng, J. Lin, F. Liu, Y. Dong and Y. Hou, Multistimuli-Regulated Photochemothermal Cancer Therapy Remotely Controlled via $\mathrm{Fe}_{5} \mathrm{C}_{2}$ Nanoparticles, ACS Nano, 2016, 10, 159-169.

21 Y. Du, Q. Jiang, N. Beziere, L. Song, Q. Zhang, D. Peng, C. Chi, X. Yang, H. Guo, G. Diot, V. Ntziachristos, B. Ding and J. Tian, DNA-Nanostructure-Gold-Nanorod Hybrids for Enhanced In Vivo Optoacoustic Imaging and Photothermal Therapy, Adv. Mater., 2016, 28, 10000-10007.

22 C. Sun, L. Wen, J. Zeng, Y. Wang, Q. Sun, L. Deng, C. Zhao and $\mathrm{Z}$. Li, One-pot solventless preparation of PEGylated black phosphorus nanoparticles for photoacoustic imaging and photothermal therapy of cancer, Biomaterials, 2016, 91, 81-89.

23 L. Wang, P. P. Yang, X. X. Zhao and H. Wang, Self-assembled nanomaterials for photoacoustic imaging, Nanoscale, 2016, 8, 2488-2509.

24 L. Nie and X. Chen, Structural and functional photoacoustic molecular tomography aided by emerging contrast agents, Chem. Soc. Rev., 2014, 43, 7132-7170.

25 L. V. Wang and S. Hu, Photoacoustic tomography: in vivo imaging from organelles to organs, Science, 2012, 335, 1458-1462.

26 J. Qiu, Q. Xiao, X. Zheng, L. Zhang, H. Xing, D. Ni, Y. Liu, S. Zhang, Q. Ren, Y. Hua, K. Zhao and W. Bu, Single $\mathrm{W}_{18} \mathrm{O}_{49}$ nanowires: A multifunctional nanoplatform for computed tomography imaging and photothermal/ photodynamic/radiation synergistic cancer therapy, Nano Res., 2015, 8, 3580-3590.

27 Z. Zhou, B. Kong, C. Yu, X. Shi, M. Wang, W. Liu, Y. Sun, Y. Zhang, H. Yang and S. Yang, Tungsten oxide nanorods: an efficient nanoplatform for tumor CT imaging and photothermal therapy, Sci. Rep., 2014, 4, 3653.

28 J. M. Luther, P. K. Jain, T. Ewers and A. P. Alivisatos, Localized surface plasmon resonances arising from free carriers in doped quantum dots, Nat. Mater., 2011, 10, 361-366.

29 T. M. Mattox, A. Bergerud, A. Agrawal and D. J. Milliron, Influence of Shape on the Surface Plasmon Resonance of Tungsten Bronze Nanocrystals, Chem. Mater., 2014, 26, 1779-1784.

30 C. Guo, S. Yin, H. Yu, S. Liu, Q. Dong, T. Goto, Z. Zhang, Y. Li and T. Sato, Photothermal ablation cancer therapy using homogeneous $\mathrm{Cs}_{\mathrm{x}} \mathrm{WO}_{3}$ nanorods with broad near-infra-red absorption, Nanoscale, 2013, 5, 6469-6478.

31 L. Wen, L. Chen, S. Zheng, J. Zeng, G. Duan, Y. Wang, G. Wang, Z. Chai, Z. Li and M. Gao, Ultrasmall
Biocompatible $\mathrm{WO}_{3-x}$ Nanodots for Multi-Modality Imaging and Combined Therapy of Cancers, Adv. Mater., 2016, 28, 5072-5079.

32 P. Kalluru, R. Vankayala, C. S. Chiang and K. C. Hwang, Photosensitization of singlet oxygen and in vivo photodynamic therapeutic effects mediated by PEGylated $\mathrm{W}_{18} \mathrm{O}_{49}$ nanowires, Angew. Chem., Int. Ed., 2013, 52, 1233212336.

33 Z. Chen, Q. Wang, H. Wang, L. Zhang, G. Song, L. Song, J. Hu, J. Liu, M. Zhu and D. Zhao, Ultrathin PEGylated $\mathrm{W}_{18} \mathrm{O}_{49}$ nanowires as a new 980 nm-laser-driven photothermal agent for efficient ablation of cancer cells in vivo, Adv. Mater., 2013, 25, 2095-2100.

34 K. Manthiram and A. P. Alivisatos, Tunable Localized Surface Plasmon Resonances in Tungsten Oxide Nanocrystals, J. Am. Chem. Soc., 2012, 134, 3995-3998.

35 W. Guo, C. Guo, N. Zheng, T. Sun and S. Liu, Cs $\mathrm{WO}_{3}$ Nanorods Coated with Polyelectrolyte Multilayersas a Multifunctional Nanomaterial for Bimodal ImagingGuided Photothermal/Photodynamic Cancer Treatment, Adv. Mater., 2017, 29, 1604157.

36 Y. Zhang, B. Li, Y. Cao, J. Qin, Z. Peng, Z. Xiao, X. Huang, R. Zou and $\mathrm{J} . \mathrm{Hu}, \mathrm{Na}_{0.3} \mathrm{WO}_{3}$ nanorods: a multifunctional agent for in vivo dual-model imaging and photothermal therapy of cancer cells, Dalton Trans., 2015, 44, 2771-2779.

37 G. Tian, X. Zhang, X. Zheng, W. Yin, L. Ruan, X. Liu, L. Zhou, L. Yan, S. Li, Z. Gu and Y. Zhao, Multifunctional $\mathrm{Rb}_{x} \mathrm{WO}_{3}$ nanorods for simultaneous combined chemophotothermal therapy and photoacoustic/CT imaging, Small, 2014, 10, 4160-4170.

38 D. Ni, J. Zhang, J. Wang, P. Hu, Y. Jin, Z. Tang, Z. Yao, W. Bu and J. Shi, Oxygen Vacancy Enables Markedly Enhanced Magnetic Resonance Imaging-Guided Photothermal Therapy of a $\mathrm{Gd}^{3+}$-Doped Contrast Agent, ACS Nano, 2017, 11, 4256-4264.

39 J. Park, K. An, Y. Hwang, J. G. Park, H. J. Noh, J. Y. Kim, J. H. Park, N. M. Hwang and T. Hyeon, Ultra-large-scale syntheses of monodisperse nanocrystals, Nat. Mater., 2004, 3, 891-895.

40 Z. Lu, C. Gao, Q. Zhang, M. Chi, J. Y. Howe and Y. Yin, Direct assembly of hydrophobic nanoparticles to multifunctional structures, Nano Lett., 2011, 11, 3404-3412.

41 J. V. Jokerst, T. Lobovkina, R. N. Zare and S. S. Gambhir, Nanoparticle PEGylation for imaging and therapy, Nanomedicine, 2011, 6, 715-728.

42 C. D. Walkey and W. C. Chan, Understanding and controlling the interaction of nanomaterials with proteins in a physiological environment, Chem. Soc. Rev., 2012, 41, 2780-2799.

43 G. Xi, S. Ouyang, P. Li, J. Ye, Q. Ma, N. Su, H. Bai and C. Wang, Ultrathin $\mathrm{W}_{18} \mathrm{O}_{49}$ nanowires with diameters below $1 \mathrm{~nm}$ : synthesis, near-infrared absorption, photoluminescence, and photochemical reduction of carbon dioxide, Angew. Chem., Int. Ed., 2012, 51, 23952399. 